九州大学学術情報リポジトリ

Kyushu University Institutional Repository

\title{
The Development of Crown of Broad-Leaved Trees
}

Aragami, Kazutoshi

University Forest, Faculty of Agriculture, Kyushu University

Yuruki, Tatsuro

University Forest, Faculty of Agriculture, Kyushu University

Setsu, Takao

University Forest, Faculty of Agriculture, Kyushu University

https://doi.org/10.5109/23891

出版情報 : 九州大学大学院農学研究院紀要. 34 (1/2)，pp.95-100，1989-11. Kyushu University バージョン：

権利関係 : 
J. Fac. Agr., Kyushu Univ., 34 (1•2), 95-100 (1989)

\title{
The Development of Crown of Broad-leaved Trees
}

\author{
Kazutoshi Aragami, Tatsuro Yuruki and Takao Setsu \\ University Forest, Faculty of Agriculture, \\ Kyushu University, Fukuoka 812, Japan \\ (Received June 23, 1989)
}

\begin{abstract}
Generally, a tall conifer tree has small branches and a single stem, and the stem usually stands erect even if crown form changes. On the other hand, a broad-leaved tree sends out many large branches and it is difficult to determine which is the leading shoot. Thereupon, we investigated the relation between stem and branch growth, and discussed the form development for broad-leaved trees growing in a group. The leading shoot of most broadleaved trees has shifted with the progress of growth. Judging from the results, it is considered that most broad-leaved trees are capable of adapting to changes in the environment by easily shifting the leading shoot.
\end{abstract}

\section{INTRODUCTION}

Generally, the growth patterns of tree stems are grouped according to either monopodial branching or sympodial branching (Shimaji and Kurata, 1980). The mode of branching affects tree form and stem straightness.

A tall conifer tree such as sugi (Cryptomeria japonica D. Don), hinoki (Chamaecyparis obtusa Endl.), momi (Abies firma S. et Z.) and tsuga (Tsuga sieboldii Carr.) show monopodial branching in which the growth of leading shoot is always greater than that of sub-branches. Accordingly, crowns show conical form. And the stem usually stands erect, even if crown form changes.

On the other hand, most broad-leaved trees send out many large branches and there is very little difference in growth between leading shoot and branches. Thus, a broad-leaved tree may take on various forms. Accordingly, it is extremely difficult to determine which is the leading shoot and to predict the development of the crown.

A natural broad-leaved forest is a combination of trees having different growth patterns. The development of a forest may involve diverse processes as evident from differences in density, distributional pattern and other features. Accordingly, it is extremely difficult to predict the ultimate figure of a young forest.

When spaces between trees are maintained properly in a stand, the trees have been found to assume their own characteristic form.

In the case of unequal spacing, tree form changes variously in the conspecific or interspecific struggle for space.

In surveying the development of broad-leaved forest, it is essential to understand the manner in which the stems and crowns of broad-leaved tree are formed. Up to the present, the form development of a tree has been studied primarily in the case of an isolated tree (Fujii et al., 1987 a ; Fujii et al., 1987 b ; Satsukawa and Takahara, 1984 ; Yamamoto and Yamaguchi, 1989), but little attention has been directed to the development in a group. 


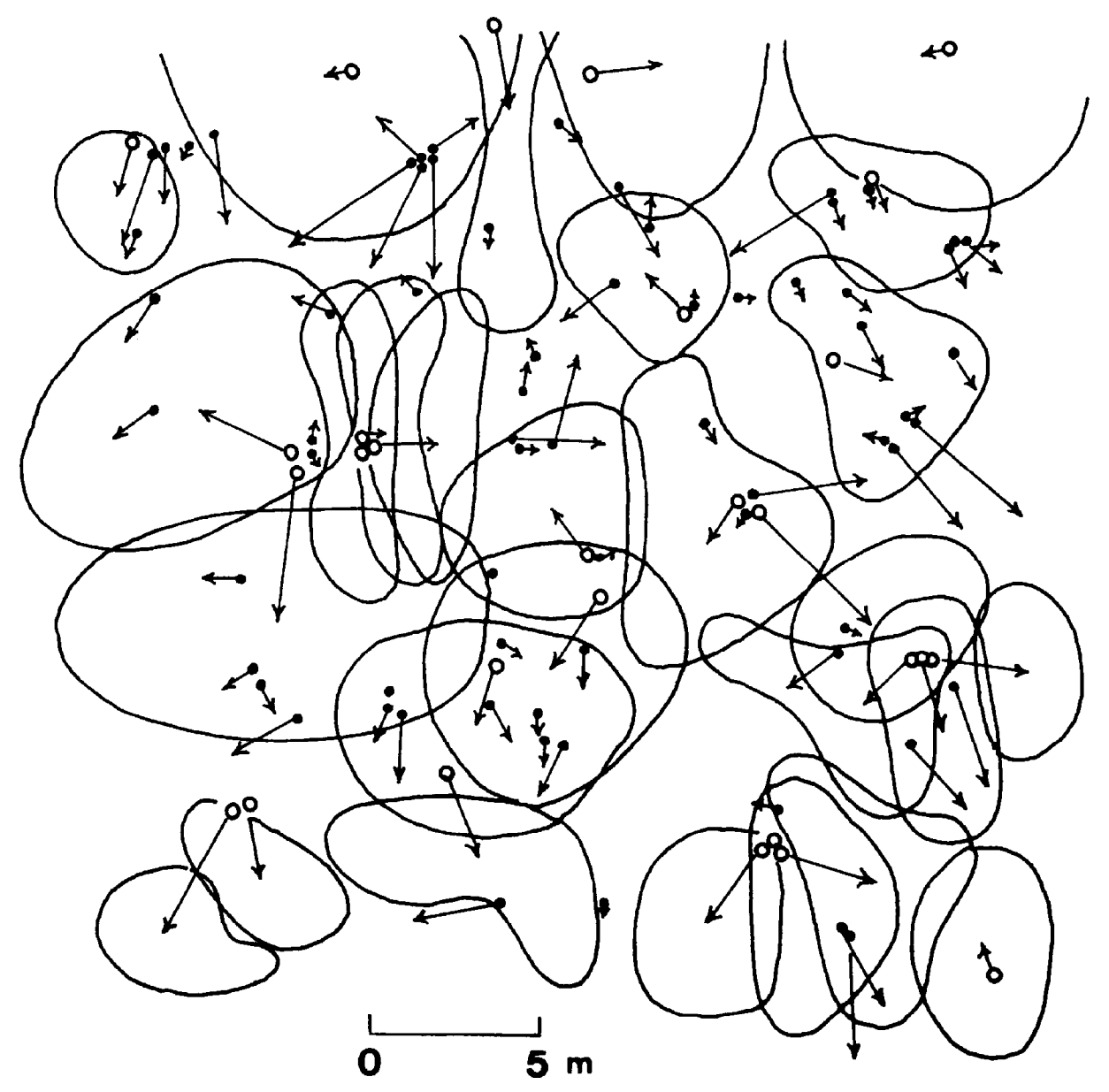

Fig. 1. Crown projection diagram of Sudajii (Castanopsis cuspidata var. sieboldii) forest.

In this paper, we investigate the relation between stem and branch growth, and discuss the form development for trees growing in a group.

\section{MATERIALS AND METHODS}

Two broad-leaved forests were investigated. One is a natural sudajii (Castanopsis cuspidata var. sieboldii) forest and the other a konara (Quercus serrata) secondary forest.

Sudajii forest is located in Hisayama-machi, Kasuya-gun, Fukuoka-ken (latitude : 33 " $40^{\prime} \mathrm{N}$, longitude : 130 " $31^{\prime} \mathrm{E}$, altitude : $250 \mathrm{~m}$, topography : middle of southwest slope, inclination of slope : 22").

Konara forest is located in Compartment 11 of the Kasuya Forest of Kyushu University in Sasaguri-machi, Kasuya-gun, Fukuoka-ken (latitude : 33" 38'N, longi- 


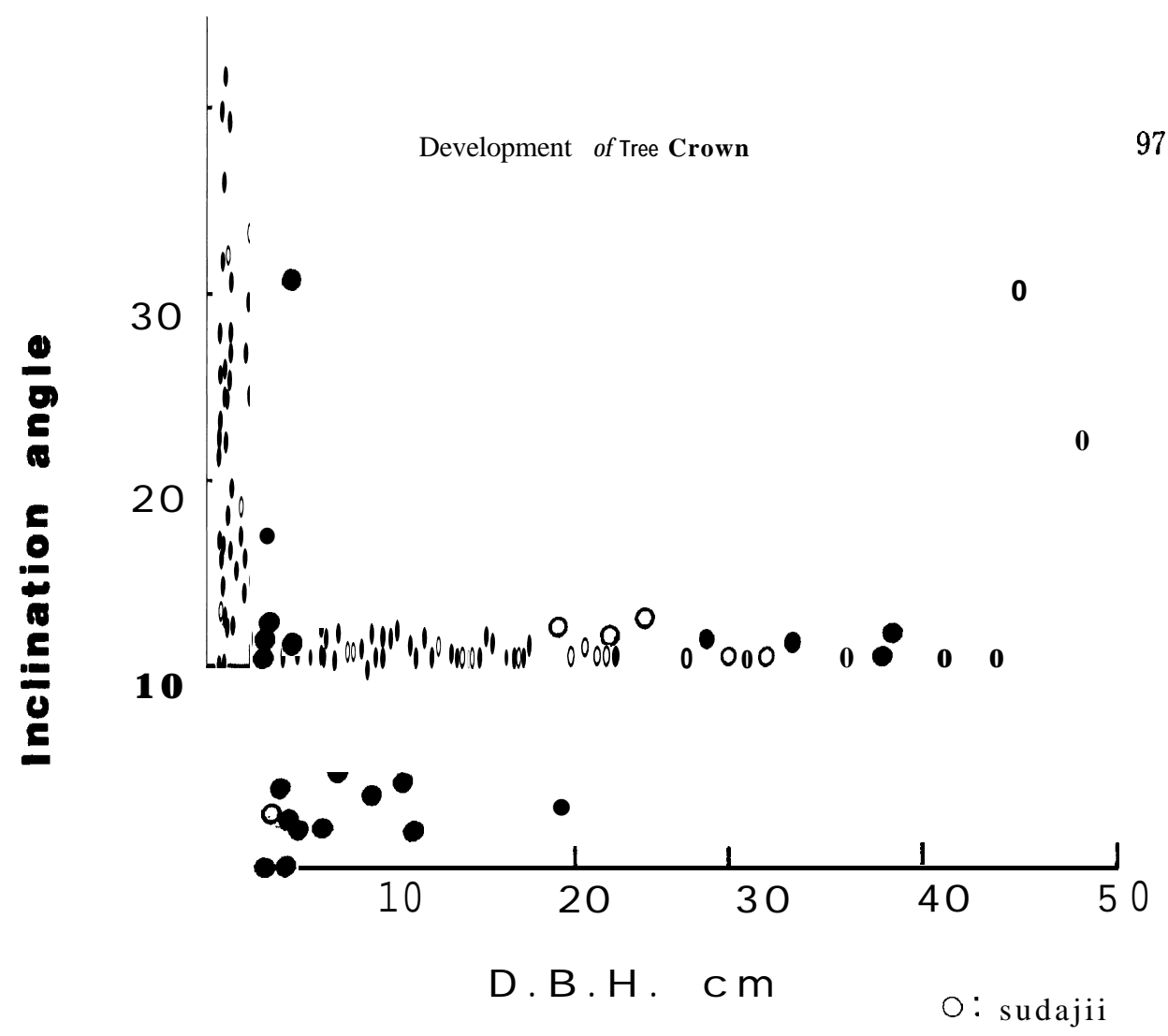

Fig. 2. Relationship between inclination angle and D. B. H.

tude : 130" 30' E, altitude : $50 \mathrm{~m}$, topography : north slope, inclination of slope : $5^{\circ}$ ).

Sudajii forest were composed of Castanopsis cuspidata Schottky var. sieboldii Nakai (dominant tree), Machilus thunbergii Sieb. et Zucc., Quercus glauca Thunb., Camellia japonica L., Ligstrum japonicum Thunb., Daphniphyllum teijsmunni Zoll, Ternstroemia gymnantheria Sprague, Ficus erecta Thunb. and so forth.

Konara forest composed of Quercus serrata Thunb. ex Murray (dominant tree), Machilus thunbergii S. et Z., Prunus jamasakura Sieb. ex Koidz., R hus succedanea L., Symplocos lucida S. et Z., Eurya japonica Thunb., Ligstrum japonicum Thunb. and so forth.

Plot $1(25 \mathrm{~m} \mathrm{X} 25 \mathrm{~m})$ was established in the sudajii forest. For all individual trees on this plot, the diameter at the breast height (D. B. H.) were measured, and the crown of upper trees were projected on the diagram. The inclination angle of a line linking the root of stem with the center of crown was measured.

Plot $2(10 \mathrm{~m} \times 10 \mathrm{~m})$ was established in the konara forest. The upper crown projection diagram was drawn. Stem analysis at $0.5 \mathrm{~m}$ intervals was carried out on a konara individual.

\section{RESULTS AND DISCUSSION}

Fig. 1 shows a crown projection diagram of a sudajii forest. This forest was comprised mainly of large-size trees. Most of the crowns were Castanopsis cuspidata var. sieboldii and Machilus thunbergii. 


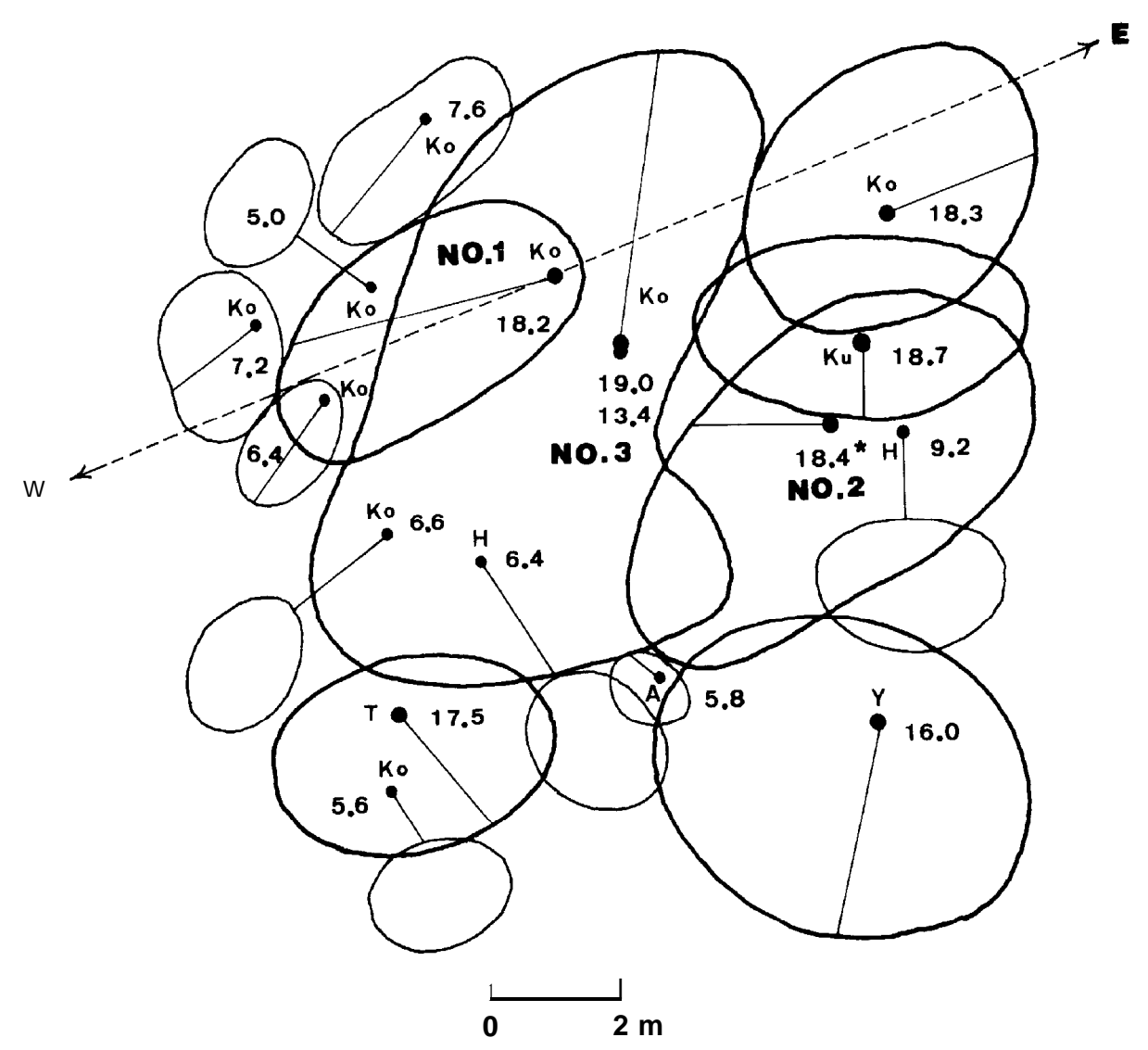

Fig. 3. Crown projection diagram of Konara (Quercus serrata) secondary stand. Ko: Quercus serrata Thunb.

$\mathrm{Ku}$ : Symplocos lucida S. et $Z$.

$\mathrm{H}$ : Rhus succedanea L.

Y: Prunus jamasakura Sieb. ex Koidz.

A : Pinus densiflora $\mathbf{S}$. et $Z$.

$\mathrm{T}$ : Machilus thunbergii $\mathbf{S}$. et $\mathrm{Z}$.

$\star$ : D. B. H. (cm)

Obviously, each upper tree expanded the crown so that as much as possible, one would not become situated upon another. The center of crown apparently did not meet the root. In the figure, deviation of the crown center from the root location is shown by an arrow. It is apparent that transformation of the crown of a broad-leaved tree is related largely to the inclination of the stem itself, in contrast to a conifer. However, the extent of stem inclination could not be determined from the figure.

Fig. 2 shows the relationship between the inclination angle and D. B. H.. Most of the small size trees also leaned largely. It is evident from the above that small size trees in poor light under the crowns of upper trees always elongate their stems and branches toward the gap of the upper canopy to obtain as much light as possible. 


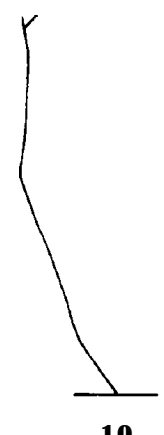

10
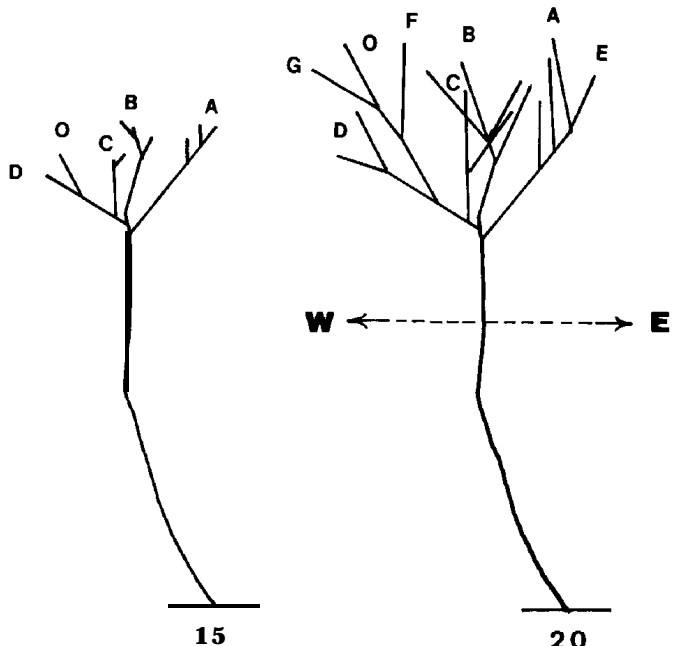

years after sprouting

Fig. 4. Growth process of the branches.

Branch development was investigated for a young konara secondary stand. In Fig. 3 , the crown projection diagram indicates most of the crowns to grow elliptically in the same way as in the sudajii stand.

Judging from the relation between the crown and stem root, all the stems appear to incline to a greater or lesser degree.

Fig. 4 shows the growth of branches of konara-NO. 1 in Fig. 3. It is quite evident that the crowns developed in a $\mathrm{W}$ direction because of oppression by adjacent konaraNO. 3. The branches comprising the present crown had showed virtually no growth at the ten years after sprouting. Only branches A and B had grown. Most of the present main branches appeared at the fifteen years after sprouting.

Branch-A elongating in an E direction was superior to the stage of 5 years ago. At the present, branch elongation in the $\mathrm{E}$ direction is suppressed by adjoining individuals and branch-O elongating in the $\mathrm{W}$ direction appears to be the leading shoot. This stem is bent at several places. This indicates that the leading shoot has shifted with the progress of growth. That is, judging from stem inclination, the leading shoot initially elongated in the $\mathrm{W}$ direction and changed to the $\mathrm{E}$ direction at a certain time. At the present, the direction has changed to the $\mathrm{W}$ direction again.

Table 1 shows lengths from the roots of the stems to the tops of the branches. The lengths are almost the same but the branches vary in size. It is especially remarkable that the length comes to remain in a fixed range even in the case of branches of such elliptical crown trees as this. The leading shoot does not become longer. Accordingly, it is difficult to decide by length alone which is the leading shoot.

This indicates that most of the branches constituting the crown of konara have the potential of becoming the leading shoot. That is, the konara tree adapted the crown to the changes in the environment by shifting the leading shoot. 
Table 1. Length from the root of the stem to the top of the branches.

\begin{tabular}{c|c|c}
\hline \multirow{2}{*}{ Branch No. } & \multicolumn{2}{|c}{ Total length $\mathrm{m}$} \\
\cline { 2 - 3 } & Tree NO. 1 & Tree NO. 2 \\
\hline A & 9.71 & 10.78 \\
B & 9.00 & 10.13 \\
C & 8.54 & 10.54 \\
D & 9.02 & 10.94 \\
E & 9.04 & 12.11 \\
F & 9.65 & 11.98 \\
G (Leading shoot) & 9.94 & 11.12 \\
O (Lea & 11.68 \\
\hline
\end{tabular}

※ Tree NO. 1 , NO. 2 : shown in Fig. 3

Generally, the growth of trees is effected by site, density and other factors. Adaptation to the environment, especially the light environment differs between broad-leaved trees and conifer trees. This difference is due to the particular mode of branching.

From the above results, we may conclude that most broad-leaved trees adapt to changes in the environment by easily shifting the leading shoot.

\section{REFERENCES}

Fujii, E., T. Yamashita, T. Anbiru and J. Asano 1987a Morphological studies on the developing process of tree form of landscape plants-A young tree of Liriodendrontulipifera L., Tech. Bull. Fac. Hort.Chiba Univ. 39: 123-133 (in japanese with English Summary)

Fujii, E., T. Yamashita, K. Koseki, T. Anbiru, T. Okinaka and J. Asano 1987b Morphological Studies on the Development Process of Tree Form of Acerbuergerianum Miq.. J. JILA, 50 (5) : 149-154 (in japanese with English Summary)

Satsukawa, A. and H. Takahara 1984 Study on the Shapes of Trees by Simulation Model J. JILA, 47 (5) : 195-200 (in japanese with English Summary)

Shimaji, K. and Kurata, S. 1980 Tree Form Development in "Tree-Form and Function-" ed. by Satoo, T. and T. Tsutsumi, Buneido, Tokyo, pp. 13-15 (in japanese)

Yamamoto, T. and E. Yamaguchi 1989 A Quick Analyzing System of Tree Form and Structure of Leaf Canopy of Fruit Trees-Development of a New System with Two Side-Photographs-Bull. Yamagata Univ., Agr.Sci., 10 (4) : 860-901 (in japanese with English Summary) 